\title{
Expiration Training Maneuver for Chronic Obstructive Pulmonary Disease with Congestive Heart Failure Grade II: A Case Report
}

\section{Nury Nusdwinuringtyas ${ }^{1}$, Siti Chandra Widjanantie ${ }^{2}$}

${ }^{1}$ Department of Physical Medicine and Rehabilitation, Dr. Cipto Mangunkusumo Hospital, University of Indonesia, Jakarta

2 Department of Physical Medicine and Rehabilitation, Persahabatan National Respiratory Hospital, Jakarta, Indonesia

\begin{abstract}
Introduction: Chronic Obstructive Pulmonary Disease (COPD) was characteristic by the inflammatory process in the airway which causes air trapping and hyperinflation, then followed by decreasing the respiratory muscle strength. Breathing training using the positive expiratory pressure (PEP) increasing respiratory muscle strength.

Methods: A case presentation of a male, age was 60 years old diagnosed as COPD by The Global Initiative for Chronic Obstructive Lung Disease (GOLD) grade 4 group D, and Chronic Heart Failure (CHF) grade II, with complication of excessive phlegm, underweight, and weakness of respiratory muscle, have PEP for 8 weeks.

Results: Spirometry evaluation before and after eight week of PEP have found; FEV1 22.12 and 22.42\%, FVC 34.24 and 56\%, FEV1/FVC 76.8 and 64\%. Respiratory muscle strength before and after PEP showed the Muscle Inspiratory Pressure (MIP) 46 and $71 \mathrm{cmH}_{2} \mathrm{O}$, Muscle Expiratory Pressure (MEP) 48 and $104 \mathrm{cmH}_{2} \mathrm{O}$. The values of Six Minute Walk Test (6MWT) evaluation by BORG modified scale before and after PEP were 11 and 13 (efforts), 2 and 3 (dyspnea), 0 and 1 (Leg Fatigue). The six-minute walking distance (6MWD) before and after PED were 170 and $190 \mathrm{~m}$, equation reference with Nury's formula showed percentage prediction before and after PEP respectively 29.2 and 32\%, $\mathrm{VO}_{2} \mathrm{Max} ; 4.96$ and $6 \mathrm{~L}$, METs; 1.41 and 1.7. The St George Respiratory Questionnaire (SGRQ) before and after PEP were 20.6 and 49.5\% (symptom), 86.6 and 45.1\% (activity), 45.5 and $18.4 \%$ (impact) and 53.6 and $42 \%$ for total.
\end{abstract}

Conclusion: Positive airway pressure exercise had beneficial effect on reducing air-trapping process in COPD and increasing the respiratory muscle strength for both expiratory and inspiratory muscle strength.

Keywords: Chronic obstructive pulmonary disease, positive expiratory pressure device, respiratory muscle strength, six minutes walking distance 


\section{ABSTRAK}

Pendahuluan: Karakteristik Penyakit Paru Obstruktif Kronis (PPOK) adalah adanya peradangan pada saluran pernafasan, yang mengakibatkan udara terperangkap dan terjadi hiperinflasi, kemudian diikuti dengan penurunan kekuatan otot respirasi. Latihan pernafasan menggunakan tekanan ekspiratori positif (Positif Expiratory Pressure - PEP) diharapkan meningkatkan kekuatan otot respirasi.

Metode: Presentasi kasus seorang laki-laki, usia 60 tahun didiagnosis dengan PPPOK grade 4 grup D oleh The Global Initiative for Chronic Obstructive Lung Disease (GOLD), disertai Gagal Jantung Kronis (Chronic Heart Failure - CHF) derajat II, dengan komplikasi adanya sputum berlebihan, berat badan terlalu rendah, dan kelemahan otot repirasi, menjalani PEP selama 8 minggu.

Hasil: Evaluasi spirometri sebelum dan sesudah delapan minggu PEP ditemukan FEV1 22.12 dan $22.42 \%$, FVC 34.24 dan 56\%, FEV1/FVC 76.8 dan 64\%. Kekuatan otot pernafasan sebelum dan sesudah PEP menunjukan tekanan inspirasi otot (Muscle Inspiratory Pressure-MIP) 46 dan $71 \mathrm{cmH}_{2} \mathrm{O}$. Tekanan ekspirasi otot (Muscle Expiratory Pressure - MEP) 48 dan $104 \mathrm{cmH}_{2} \mathrm{O}$. Nilai dari evaluasi Tes Berjalan Enam Menit (6MWT) oleh skala modifikasi BORG sebelum dan sesudah PEP adalah 11 dan 13 (usaha), 2 dan 3 (dispneu), 0 dan 1 (Kelelahan kaki). Jarak berjalan enam menit (six-minute walking distance - 6MWD) sebelum dan sesudah PEP adalah 170 dan $190 \mathrm{~m}$. Referensi persamaan dengan formula Nury menunjukkan prediksi persentasi sebelum dan sesudah PEP adalah 29.2 dan 32\%, $\mathrm{VO}_{2}$ Maks; 4.96 dan 6 L, METs; 1.41 dan 1.7. Kuisioner St George Respiratory (SGRQ) sebelum dan sesudah PEP adalah 20.6 dan 49.5\% (gejala), 86.6 and $45.1 \%$ (aktivitas), 45.5 and $18.4 \%$ (dampak) dan 53.6 dan $42 \%$ secara keseluruhan.

Kesimpulan: Latihan tekanan positif saluran nafas bermanfaat mengurangi terperangkapnya udara pada PPOK dan meningkatkan kekuatan otot nafas.

Kata kunci : PPOK, alat tekanan ekspiratori positif, kekuatan otot respirasi, jarak berjalan enam menit

\section{Correspondent Detail:}

\section{Nury Nusdwinuringtyas}

Email: nury_nus@yahoo.com

Department of Physical Medicine and

Rehabilitation,

Dr. Cipto Mangunkusumo Hospital,

University of Indonesia

Jakarta, Indonesia

\section{INTRODUCTION}

Chronic Obstructive Pulmonary Disease (COPD)

was characteristic by persistent respiratory symptoms and airflow limitation that caused by airway and alveolar abnormalities. ${ }^{1}$ The inflammation and peripheral airway constriction causes Force Expiratory Volume in the first second (FEV1) decreases. ${ }^{1}$ The persistent inflammation on airway caused air trapping in alveoli and caused hyperinflation. Hyperinflation will affected on respiratory muscles, by decrease of inspiratory volume and dyspnea while doing exercise. ${ }^{1}$ The hyperinflation causes decreasing in 
respiratory muscle strength, i.e. inspiratory and expiratory muscles.

The hyperinflation lead inspiratory muscle to tighten at end of expiration. ${ }^{2}$ The respiratory muscle is striated muscle that have striated muscle micro structure. ${ }^{2}$ Muscle contraction occurs as sliding motion of actin and myosin. ${ }^{3}$ The hyperinflation in COPD caused diaphragm muscle always in contraction position, so myosin protein in myofibril to be closer each other and decreased inspiratory muscle strength. ${ }^{3}$

Doing Breathing by the PEP device is similar with breathing by pursed-lips method, which the function is to exert expiratory pressure, by producing pressure on the mouth. This method transmitted pressure by keeping the airway open during expiration, and prevents premature airway closure. ${ }^{4}$ Saridhar et al. found an improvement in inspiration capacity and vital capacity by reducing dynamic hyperinflation during exercise in 32 COPD patients who used the PEP threshold at a pressure of $10-15 \mathrm{cmH}_{2} \mathrm{O}$. This assist in reducing dyspnea during exercise \& improves exercise performance in COPD patients. $^{5}$ Increased expiratory volume due to decreased airway collapse also results in increased lung emptying, lower functional residual cardiorespiratory (FRC), improved ventilation distribution and gas exchange. While there are decreasing of hyperinflation decreases in breathing, thus the mechanical of inspiratory muscles be more effective, then the congestion became lesser. Reducing of hyperinflation may improved the distribution of ventilation and improving gas exchange in COPD. ${ }^{3}$

This case study discusses a COPD on a 60 -year old male with hyperinflation, and is treated by breathing exercise, using PEP.

\section{CASE REPORT}

The patient is 60 years old male, a heavy smoker with Brinkman index 960, with the symptoms are shortness of breath after walk more than 20 meter and performing light activity (bathing and cleaning the toilet), prolonged cough particularly in the morning, productive phlegm that difficult to remove, and weight loss. Activity of daily living is performed by mild dependent (Barthel index score 19). He has history of Chronic Kidney Disease Grade III, Chronic Heart Failure with Functional class II, hypertension, hypercholesterolemia. The symptom controlled by taking a rest, using salbutamol inhaler, and using two pillows while lying on the bed.

The physical examination has found the signs of underweight, limitation chest expansion (2-3-3 $\mathrm{cm})$. There was a slight kiphotic on thoracal, with barrel chest appearance. Chest x-ray has showed emphysematous lung and bilateral pleural effusion. Echocardiography has showed global normokinetic with $79 \%$ on ejection fraction, disfunction of diastolic relaxation, mild tricuspid regurgitation, and disfunction of left ventricle diastolic.

Laboratory examination has found a decreasing of kidney function, hyponatremia, hypokalemia and hypochloride.

Pulmonary special examination have found the score of modified medical research council (mMRC) score was 3, The COPD assessment test (CAT) score was 24, St George Respiratory Questionnaire (SGRQ) has showed 20.6\% 
for Symptom, $86.6 \%$ for Activity, $45.5 \%$ for Impact and $53.6 \%$ for total. Peak flow meter examination showed low peak flow rate $(90 \mathrm{ml} /$ minute) and peak cough flow (90 $\mathrm{ml} /$ minute). Spirometry examination has showed pulmonary mixed obstructive restrictive, i.e. FEV1 $22.12 \%$, FVC $34.24 \%$ and FEV1/FVC 76,8\%. Respiratory muscle strength examination has showed Muscle Inspiratory Pressure (MIP) was $46 \mathrm{cmH}_{2} \mathrm{O}$ and Muscle Expiratory Pressure (MEP) was48 $\mathrm{cmH} 2 \mathrm{O}$. Examination of BORG modified scale before Six Minute Walk Test (6MWT) has revealed the score, i.e. 11 for efforts, 2 for dyspnea, 0 for Leg Fatigue and after the test become 13 for efforts, 3 for dyspnea and 1 for leg fatigue.

The six minute walking distance (6MWT) was $170 \mathrm{~m}$, by Nury's formula has showed the percentage prediction was $29.2 \%$ (prediction of $581.9 \mathrm{~m}$ ), $\mathrm{VO}_{2} \mathrm{Max} 4.96 \mathrm{~L}$ and METs 1.41, which mean a low endurance of cardiorespiration.

The patient has diagnosed as COPD Gold grade 4 group D and CHF grade II, with complicating factor, i.e. excessive production of phlegm, underweight, decreased respiratory muscle strength and decrease chest expansion. The Rehabilitation Medicine program prescribed were chest therapy by breathing exercise with pursed lip breathing, diaphragm breathing and infra-red therapy; aerobic exercised with static cycling start from as tolerated progression until low intensity (30\% of work rate); exercise with Positive Expiratory Pressure (PEP) by 16
$\mathrm{cmH}_{2} \mathrm{O}$ of pressure, every day for 15 minutes. The pressure of PEP adjusted as subject tolerant to maintain time of expiration three times longer than inspiration.

The evaluation after 8 weeks programs have shown the FEV1 was $22.42 \%$, the FVC was $56 \%$, the $\mathrm{FEV} 1 / \mathrm{FVC}$ was $7 \%$, the MIP was $71 \mathrm{cmH}_{2} \mathrm{O}$ and the MEP was $104 \mathrm{cmH}_{2} \mathrm{O}$. St George Respiratory Questionnaire (SGRQ) has showed $49.5 \%$ for symptom, $45.1 \%$ for activity, $18.4 \%$ for Impact and $42 \%$ for total. The modified scale of BORG before 6MWT were 9 for efforts, 1 for dyspnea, 0 for leg fatigue and after is 13 for efforts, 3 for dyspnea, 1 for leg fatigue. The values of 6MWD after PEP were $190 \mathrm{~m}$, with $32 \%$ of prediction, $6 \mathrm{~L}$ of VO2Max and 1.7 of METs.

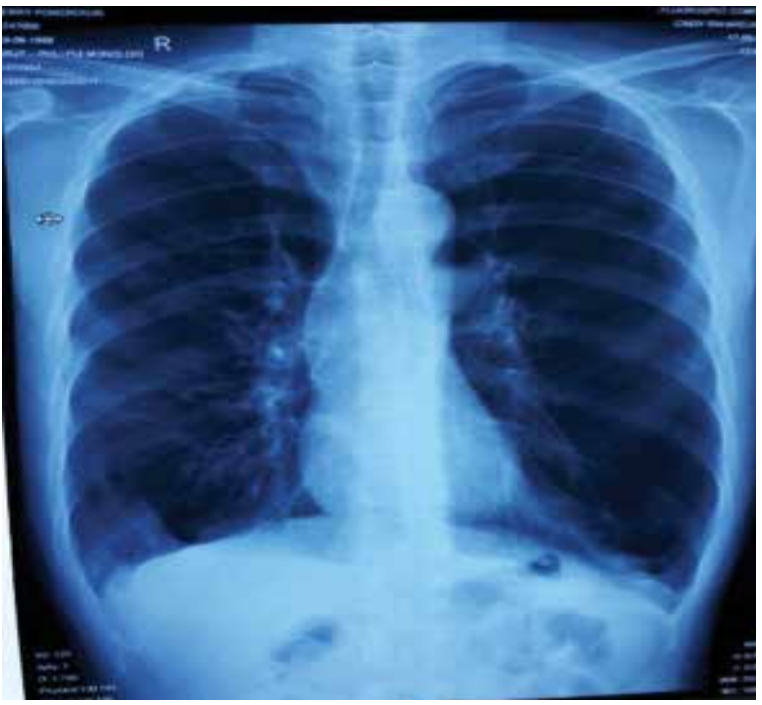

Figure 1. Result of Chest X-Ray

(Emphysematous lung with bilateral pleura effusion) 


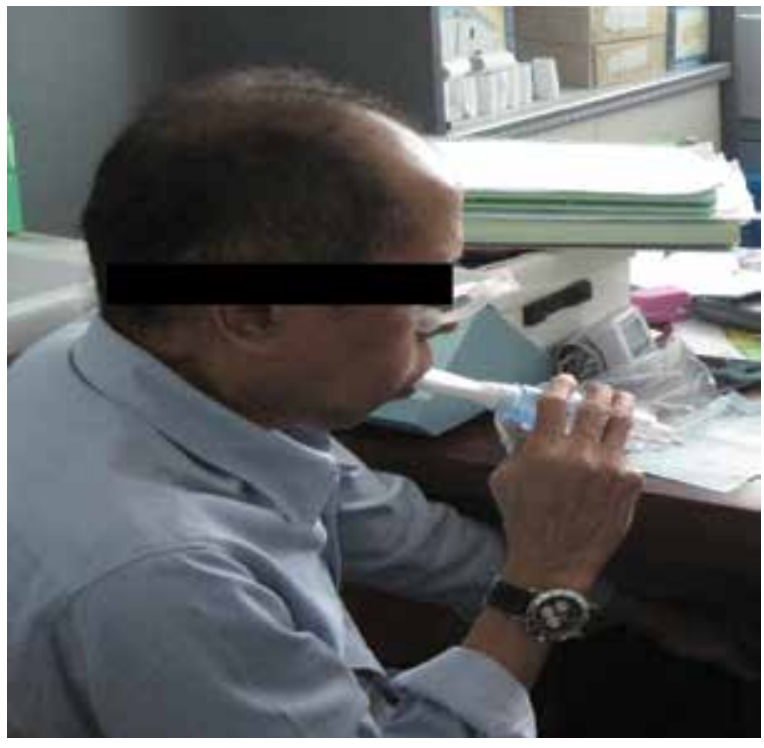

Figure 2. The patient used threshold Positive Expiratory Pressure Device

\section{DISCUSSION}

There was a limitation of air flow during breathing due to an increasing of pulmonary compliance by emphysema in COPD. ${ }^{6}$ The limitations of air flow has seen on decreasing of forced expiratory volume (FEV1) was $22.12 \%$ ( $<30 \%$ predicted $)^{1}$, accompanied with the symptoms by GOLD has shown the score was 4 , which mean the severe dysfunction. The decreased of FEV1 caused increasing of the air volume that remaining in the lung at the end of spontaneous expiration, thus the functional residual capacity (FRC) increasing, which called the hyperinflation. ${ }^{8}$ There are two type of hyperinflation, i.e. the static and the dynamic. ${ }^{8}$ The static hyperinflation is an equilibrium between the end of inspiratory lung volume (EILV) and the FRC, which determined by the passive pressure-volume relationship. ${ }^{8}$ In the healthy subject, the elastic recoil pressure of respiratory system decrease progressively during expiration. However, in COPD with emphysema, the elasticity of lung recoil pressure reduces. ${ }^{8}$ The dynamic hyperinflation is increase in the end of expiratory lung volume (EELV) above the resting value during exercise. ${ }^{9}$ aged 65 years $(48-79$ years

The common symptom of COPD is dyspnea, ${ }^{1}$ due to the static hyperinflation and air flow limitation that lead to dynamic hyperinflation. ${ }^{10}$ The increasing of hyperinflation has impact on several organs, i.e. neck muscles, the diaphragm, and the chest wall muscles. ${ }^{2}$ The diaphragm muscle has shorten and displace into a suboptimal position of length-tension curve. $^{2}$ In healthy subjects, the $30-40 \%$ shortening of diaphragm occurred between FRC and total lung capacity (TLC), while in COPD, the FRC exceeding, that lead shortening of diaphragm. ${ }^{2}$ This condition has reduced the inspiratory muscle strength. ${ }^{11} \mathrm{~A}$ study by Nam-Sik Kim, et al showed that MIP may better reflect of the severity of COPD compare to MEP, this study showed that both MIP and MEP reduced in COPD patients. ${ }^{11}$ In this case study has revealed the lower of MIP was $46 \mathrm{~cm} \mathrm{H20.} \mathrm{Pessoa} \mathrm{et} \mathrm{al} \mathrm{make} \mathrm{reference}$ value for maximal inspiratory pressure from a meta-analysis, the mean normal value for Men 60-69 years old was 92,7 (84,6-100,8) $\mathrm{cm} \mathrm{H}_{2} 0 .{ }^{12}$ In this case study, the MEP was 48 $\mathrm{cm} \mathrm{H}_{2} 0$, that lower than reference value 112 , $02 \mathrm{~cm} \mathrm{H}_{2}$ 0. (Formula prediction: $117-(0,83 \mathrm{x}$ age). ${ }^{13}$ Convenient, and noninvasive indices of respiratory muscle strength at the mouth, but standards are not clearly established. We review recent literature, update the 2002 American Thoracic Society/European Respiratory Society statement, and propose as the best choice using a flanged mouthpiece 
for reference values and lower limit of normal (LLN Decreasing of expiratory pressure has related to mucociliary clearance and impaired of ventilation function.

Decreased in inspiratory muscle strength in hyperinflation caused position of diaphragm is flat (contraction position). ${ }^{2}$ According to length-tension relationship, for muscle to contraction, muscle protein called actin and myosin must interact with each other, they can't interact optimally when they are too far away or too close from each other. ${ }^{3}$ The contraction position of diaphragm caused muscle protein actin and myosin to shift closer thus decreased in inspiratory muscle. ${ }^{2}$

Even though there is a decreased in MIP, we used rehabilitation that reduced air trapping. Reducing air trapping will make diaphragm muscle, as main inspiration muscle, more able to approach the optimal resting position. ${ }^{14}$ Positive expiratory pressure (PEP) is a non-invasive ventilation to improve exercise tolerance. The application of PEP increase intraluminal airway pressure and moves equal pressure point (EPP) back to the upper airway, reducing dynamic compression and subsequently limiting pulmonary hyperinflation. ${ }^{15}$ In this study, patient got PEP exercise $16 \mathrm{cmH}_{2} \mathrm{O}$ for 4 weeks. After evaluation, there is an increased in both MIP and MEP, MIP from $46 \mathrm{cmH}_{2} \mathrm{O}$ to $71 \mathrm{cmH}_{2} \mathrm{O}$ and MEP from $48 \mathrm{cmH}_{2} \mathrm{O}$ to $104 \mathrm{cmH}_{2} \mathrm{O}$. There is no different change in spirometry examination, but there is an increased in 6MWT, which 6MWD from $170 \mathrm{~m}$ to $190 \mathrm{~m}, \mathrm{VO}_{2} \mathrm{Max}$ from $4.96 \mathrm{~L}$ to $6 \mathrm{~L}$ and METs from 1.41 to 1.7. there is also increased of FVC from $34.24 \%$ to $56 \%$ showed hyperinflation reduction.
Some study showed that expiratory muscle exercise can effect inspiratory muscle to increase. Mascardi, et al. study about effect of temporary PEP between outpatient, in hospital and control showed increased of both MEP and MIP in patient with PEP than control. ${ }^{14}$ Mean MIP increase $3 \mathrm{cmH}_{2} \mathrm{O}$ and MEP increase $3.4 \mathrm{cmH}_{2} \mathrm{O}^{14}$ Thomas et al study compared between respiratory muscle training (RMT) group and control group showed that in RMT group average MIP increased $19.7 \mathrm{cmH}_{2} \mathrm{O}$ and average MEP increased $20.3 \mathrm{cmH}_{2} \mathrm{O}$, but both decreased in control group. ${ }^{11}$

Respiratory muscles exercise by expiration maneuver as pursed lip breathing will open airway due to a pressure, lead to reducing of the air trapping and mucus clearance. ${ }^{16}$ The flow out air that will oscillate the airway and caused mobilization of the mucus. ${ }^{16}$ Laura et al study has proven that pursed lips breathing reduced the dynamic hyperinflation in COPD. The study has showed the dynamic hyperinflation in pursed lip breathing group (TG litter $0.19 \mathrm{~L}$ ) was lower than non-pursed lip breathing group ( TG Littre 0.31 L). ${ }^{17}$ A systematic study by Borge et al, has reviewed the 642 studies has showed that respiratory muscle training has positive effects on breathlessness, fatigue, and disease specific quality of life (QOL). ${ }^{18}$ Potdar and Snehal have found the effect of breathing control and pursed-lip breathing in COPD after one week using expiratory flow rate has shown the purse lip breathing group has average expiratory flow rate was $258.33 \pm 11.67 \mathrm{~L} / \mathrm{min}$ and breathing controlled group has average expiratory flow rate was $193.67 \pm 13.25 \mathrm{~L} / \mathrm{min}$, that mean a significant improvement of expiratory flow rate by pursed lip breathing. ${ }^{19}$ 


\section{CONCLUSION}

Breathing exercise using a positive expiratory pressure (PEP) device increase the expiratory and inspiratory muscle strength in COPD with GOLD grade 4 group D with CHF grade II.

\section{REFERENCES}

1. Kim S, Oh J, Kim YI, Ban HJ, Kwon YS, Oh IJ, Kim KS, Kim YC, Lim SC. Differences in classification of COPD group using COPD assessment test (CAT) or modified Medical Research Council (mMRC) dyspnea scores: a crosssectional analyses.. BMC Pulm Med. 2013; 3(13):35.

2. Gagnon P, Guenette JA, Langer D, et al. Pathogenesis of hyperinflation in chronic obstructive pulmonary disease. Int $\mathrm{J}$ Chron Obstruct Pulmon Dis. 2014;9:187201. doi:10.2147/COPD.S389344.

3. Petrovic M, Reiter M, Zipko H, Pohl W, Wanke T. Effects of inspiratory muscle training on dynamic hyperinflation in patients with COPD Int J Chron Obstruct Pulmon Dis. 2012; 7:797-805

4. Lee JS, Kim SO, Seo JB, Lee JH, Kim $\mathrm{EK}$, Kim $\mathrm{TH}$, et al. Longitudinal lung volume changes in patients with chronic obstructive pulmonary disease. Lung. 2013; 191(4):405-12.

5. Gagnon P, Guenette JA, Langer D, Laviolette L, Mainguy V, Maltais F, et al. Pathogenesis of hyperinflation in chronic obstructive pulmonary disease. Int $\mathrm{J}$ COPD. 2014;9:187-201.
6. Frisk B, Espehaug B, Hardie JA, Strand LI, Moe-Nilssen R, Eagan TML, et al. Airway obstruction, dynamic hyperinflation, and breathing pattern during incremental exercise in COPD patients. Physiol Rep. 2014;2(2):e00222.

7. Soffler MI, Hayes MM, Schwartzstein RM. Respiratory Sensations in Dynamic Hyperinflation: Physiological and Clinical Applications. Respir Care. 2017;62(9):1212-23.

8. Jimborean G, Ianosi ES, Croitoru A, Szasz S, Postolache P. Respiratory muscle training in chronic obstructive pulmonary disease. Pneumologia. 2017;66(3):12830.

9. Sclauser Pessoa IMB, Parreira VF, Fregonezi GAF, Sheel AW, Chung F, Reid WD. Reference values for maximal inspiratory pressure: A systematic review. Can Respir J. 2014;21(1):43-50.

10. Evans JA, Whitelaw WA. The Assessment of Maximal Respiratory Mouth Pressures In Adults. 2009;54(10):1348-59.

11. Mascardi V, Grecchi B, Barlascini C, Banfi P, Nicolini A. Effectiveness of temporary positive expiratory pressure (T-PEP) at home and at hospital in patients with severe chronic obstructive pulmonary disease. $\mathrm{J}$ Thorac Dis. 2016;8(10):2895-902.

12. Aalstad LT, Hardie JA, Espehaug B, Thorsen E, Bakke PS, Eagan TML, Frisk B. Lung hyperinflation and functional exercise capacity in patients with COPD - a three-year longitudinal study. BMC Pulm Med. 2018; 18(1):187. 
13. Puente-Maestu L, Stringer WW. Hyperinflation and its management in COPD. Int J Chron Obstruct Pulmon Dis. 2006;1(4):381-400.

14. Pereira De Araujo CL, Karloh M, Dos Reis CM, Palú M, Mayer AF. Pursed-lips breathing reduces dynamic hyperinflation induced by activities of daily living test in patients with chronic obstructive pulmonary disease: A randomized crossover study. J Rehabil Med. 2015;47(10):957-62.
15. Hagen KB, Borge CR, Mengshoel AM, Wahl AK, Omenaas E, Moum T. Effects of controlled breathing exercises and respiratory muscle training in people with chronic obstructive pulmonary disease: results from evaluating the quality of evidence in systematic reviews. BMC Pulm Med. 2014;14(1).

16. Potdar S. A Comparative Study between the Effect of Breathing Control and Pursed Lip- Breathing Exercises in COPD Patients on Expiratory Flow Rate. J Physiother Res. 2018;2(4):1-3. 